\title{
Competency-based English Teaching and Learning: Investigating Pre-service teachers of Chinese's Learning Experience
}

\author{
Ruth Ming Har Wong \\ The Hong Kong Institute of Education \\ English Department
}

Received: 13 August 2007 / Accepted: 29 September 2007

ISSN: $1697-7467$

\begin{abstract}
English competency is known as one of the crucial skills in various social contexts in Hong Kong. In tertiary educational setting, English courses do not focus solely on the development of the four language skills. Rather, they put emphasis on the application of English Language for academic use or instrumental use. This paper will investigate the effectiveness of the implementation of competency-based ESL teaching and the learning situation of a group of 70 pre-service teachers of Chinese in a Hong Kong tertiary institute. This paper also intends to draw implications from our findings to answer the following questions: (1) How do tertiary students respond to competencybased ESL teaching and learning? (2) What are the difficulties in implementing competencybased approach? (3) What implications has competency-based ESL teaching and learning drawn to assessment and material design in Hong Kong context? Through answering the above questions, it is hoped that light can be shed on competency-based ESL researches and give insights to the development of competency-based ESL teaching in terms of material design and assessment.
\end{abstract}

Key words: competency-based ESL teaching and learning; assessment; material design.

RESUME: La competencia en inglés se entiende como una de las destrezas cruciales en varios contextos sociales de Honk Kong. En la educación superior, los cursos de inglés no se centran sólo en las cuatro destrezas del lenguaje sino que ponen más énfasis en la aplicación de la lengua inglesa para uso académico o instrumental. Este trabajo investiga la efectividad de la puesta en práctica de una enseñanza basada en competencias y la situación de aprendizaje en la que se encuentran 70 alumnos que serán profesores de chino en un centro de educación superior intentando dar respuesta a preguntas tales como de qué manera responden estos alumnos a la enseñanza y el aprendizaje basado en tareas, qué dificultades aparecen al aplicarlo y cuáles son los efectos sobre la evaluación y la elaboración de materiales, intentando así iluminar futuras investigaciones, desarrollos de modelos de evaluación e incluso la mejora en los recursos.

Palabras clave: enseñanza/aprendizaje del ILE basado en la competencia, evaluación, diseño de materiales. 


\section{INTRODUCTION}

In Hong Kong, English is the most important foreign language to be learnt for historical,'political and economical reasons (Johnson, 1998; Pennycook, 1995) and it has been a compulsory subject in schools since the British colonial years. However, people in Hong Kong are more eager to learn Putonghau after the colonial years (Shanghai Daily, 2007) as predicted by Lord (1987), Kwo (1994) and Pierson (1994) long before the handover of sovereignty. With the implementation of "Biliterate and Trilingual" language education, 90\% of Hong Kong secondary schools were to implement mother tongue education (using Cantonese to teach all subjects except language-based subjects) and use Putonghau to teach Chinese language to mark as a sign of national integration and decolonialisation. Pre-service teachers of Chinese are therefore inevitable eager to better equip themselves by learning Putonghau.

However, some universities in Hong Kong still require year one students to take an English foundation course regardless of their major. English courses emphasizes language in use and its applicability in academic writing and English for specific purposes. Are these language objectives catered for pre-service teachers of Chinese?

In the Year 1 English course, students are assessed against a set of measurable description of skills which is known as competency-based language teaching and learning (CBLT). The rationale for adopting competency-based teaching and learning is to help students better orientate their goals of learning in the hope that their learning strategies can be effectively directed and repositioned through the learning goals and language targets. How do preservice teachers of Chinese react to the competency-based English course? To answer the above mentioned questions, this paper aims to investigate the effectiveness of the implementation of competency-based ESL teaching and the learning with the sample size of 70 tertiary students majoring in Chinese Language teaching.

This paper also attempts to draw implications from findings to answer the following questions: (1) How do pre-service teachers of Chinese respond to competency-based ESL teaching and learning? (2) What are the difficulties in implementing competency-based approach? In answering the above questions, lights can be shed on future researches related to competencybased teaching, and draw implications to the development of material design and assessment.

\section{What IS CBLT?}

Competency-based education (CBE) emerged in the 1970s in the US. It referred to an educational movement that advocated defining educational goals in terms of precise measurable description of the knowledge, skills, and behaviours students should possess at the end of a course of study (Guskey, 2005). Recent researches mainly focused on studying the CBLT on the aspects of vocational training (Chyung et al., 2006; Jackson et al, 2007; Jang \& Kim, 2004; Jorgensen, 2005; Kaslow, 2004; Mulder et al, 2007), information technology (Caniels, 2005; Chang, 2006, 2007; Sampson et al., 2007) or its impact on general education (Baines \& Stanley, 2006; Biemans et al., 2004). CBLT was an application of the principles of CBE to language teaching. Language programs that were work-related and survival-oriented adopted such an approach in the end of 1970s. 
CBLT is a teaching approach which focuses on the outcomes of language learning. CBLT emphasises what learners are expected to achieve with the target language. In other words, the approach sees outputs very importantly rather than the learning process. This means, starting with a clear picture of what is important for students to be able to do, then organising curriculum, instruction, and assessment to make sure this learning ultimately happens. The keys to having a competency-based system include developing a clear set of learning outcomes around which all of the system's components can be focused, and establishing the conditions and opportunities within the system that enable and encourage all students to achieve those essential outcomes. Recent studies mostly emphasized on researching how CBE relates to curriculum planning (Williamson, 2007) and assessment (Baartman et al, 2006; Barrie, 2006; Curtis \& Denton, 2003; Heideman, 2005; Nahrwold, 2005).

CBLT is based on a functional perspective on language teaching and its framework is often tailored to meet learners' needs and the language skills they need can be fairly accurately predicted or determined. CBLT also has a notion that language form can be inferred from language function. That is, course designers should accurately predict the vocabulary and structures that are possibly to be encountered in that particular situation and they can be organized into teaching and learning units. Learners are expected to meet standards framed around goals which are explicated by descriptors, sample progress indicators and classroom vignettes with discussions. Definition of a series of short-term goals are clearly given and each builds upon the one before so that learners advance in knowledge and skill.

Docking (1994) summarized what CBLT is: "it is designed not around the notion of subject knowledge but around the notion of competency. The focus moves from what students know about language to what they can do with it. The focus on competencies or learning outcomes underpins the curriculum framework and syllabus specification, teaching strategies, assessment and reporting. Instead of norm-referencing assessment, criterion-based assessment procedures are used in which learners are assessed according to how well they can perform on specific learning tasks (p.16)."

The positive consequence of implementing CBLT is that it serves as an agent of change and it improves teaching and learning (Docking, 1994). Since competency-based approaches to teaching and assessment offer teachers an opportunity to revitalize their education and training programmes, quality of assessment can be improved, and the quality of teaching and students learning will be enhanced by the clear specification of expected outcomes and the continuous feedback that competency-based assessment can offer.

The characteristics of CBE were described by Schneck (1978), "Competency-based education has much in common with such approaches to learning as performance-based and is adaptive to the changing needs of students, teachers and the community... (p.vi)" That is, what students learn depends on the needs of the stakeholders. However, who are the "stakeholders"? Whose needs are these? Community's or learners'? In this paper, I intend to evaluate the effectiveness of implementing CBLT . If learners are clear that English is a potent element leading to career prospect and advancement, they have no objection to learning and improving English. However, there are English learners who see English as relatively less important and many of them take English courses merely for the sake of fulfilling the graduation criteria set by the institute. Through implementing competency-based approach, I hope to investigate students' attitudes towards English learning. 


\section{Operational defintion of COMPetency}

Finding a definition for "competency" is problematic for there are too many. There are two types of competencies according to Bunda and Sanders (1979). One type of definitions conceives of competence as a hypothetical construct. The second type of competence refers to a standard of performance either implicitly or explicitly.

For the first type of competency, it is much like the words, "skill", "achievement", and "intelligence" constructs. "Competency" in this use fits into some conceptual frameworks. When curriculum specialists talk of "collecting lists of competencies", they are using the term to refer to a construct. However, the breadth of the construct definition varies greatly. In some uses of the construct definition, competency is broader than the word "skills" and refers to a combination of cognitive, affective, psychomotor skills. Other individuals use competency as synonymous with behavioural objective which is generally a restrictive definition of a skill. For the second type of competence which refers to a standard of performance either implicitly or explicitly, the term closely parallels definitions of mastery or criterion levels of performance. This paper adopted the broader definition which defines competency is a combination of social, cognitive and communicative skills as the operational definition.

\section{RESEARCh QUESTIONS}

This study aimed to look into the effectiveness of CBLT and see if there is a total correlation. To answer this questions, several constituents were broken into for investigation.

RQ1: Under the implementation of competency-based language course, how do the pre-service teachers of Chinese respond to it, particularly in the aspects of course design and assessment?

$\boldsymbol{R Q 2 :}$ To what extent can students acquire and employ the study skills required by the language course?

RQ3: What are the outcome of learning under the implementation of CBLT?

\section{Methods}

\subsection{Sampling}

In this study, 70 pre-service teachers of Chinese were invited and given questionnaire to express their views on CBLT. Since only freshmen of the teacher training institute were required to take English course, they were all invited to participate in this study on a voluntary basis. Participants were assured that the data collected would only be used for the sole purpose of the study. These students of a teacher training institute all received a grade D or $\mathrm{E}$ in Use of English in their Hong Kong Advanced Level Examination, of which 60 percent of all candidates would receive while 20 percent would get Grade A to Grade C and 20 percent would receive a failing grade. That is, this group of pre-service teachers of Chinese only master an average level of English proficiency. 


\subsection{Instruments}

In this study, questionnaires were distributed with the purpose to elicit participants' responses and views on CBLT. There were two questionnaires for students to fill in this study, of which questions focused on their preferences on learning English, how often they employed the skills learnt in the course and if they believed they had successfully acquired the skills which the course designed for them to acquire.

\subsubsection{Questionnaire 1}

The questionnaires were designed based on four major issues of CBLT which were students' preference for learning English, students' needs for learning English, assignment and assessment. The questionnaire employed a 6-point scale for participants to indicate their answers (6-strongly agree, 5-agree, 4-tend to agree, 3-tend to disagree, 2-disagree and 1strongly disagree). A reliability test on the 16-item questionnaire was run to test if there is an internal consistency of all the items set. Reliability coefficient (Cronbach alphas) for items set was high (, which means the internal consistency of the 16 items in the questionnaire was high.

Table 1. Reliability Statistics

\begin{tabular}{|l|l|l|}
\hline Cronbach's Alpha & $\begin{array}{l}\text { Cronbach's Alpha Based } \\
\text { on Standardized Items }\end{array}$ & N of Items \\
\hline 0.862 & 0.965 & 16 \\
\hline
\end{tabular}

Cronbach's Alpha shows 0.952 which signifies high reliability of questionnaire set.

\subsubsection{Questionnaire 2}

Another questionnaire constructed was used to investigate what studying skills respondents employed and whether they believed they had successfully acquired the skills. The questionnaire was designed and modified based on Benson's (2001) study. Since the questionnaire only required respondents to indicate the frequency of they employ certain studying skills and whether they had successfully acquired them, no internal consistency test was needed for validating this questionnaire.

To conduct the survey, the researcher explained the purpose of the research to the participants before they answered the questionnaires. Respondents were given the questionnaires during the lecture time for a module titled "Foundations in English". The questionnaires were worded in simple English to ensure respondents were able to understand it. Respondents were reminded that their participation was completely voluntary. Informed consent forms were distributed. Respondents were reminded that data collected would only be used for the sole purpose of the current study. Respondents were given 20 minutes to answer the questionnaires and the researcher also stayed in the classroom to answer any questions raised. 


\subsubsection{Interview}

Among the 70 students, 10 of them were to be interviewed to elicit further responses on what preferences they had for English learning and why. The 10 students were all randomly chosen. Their responses were to be used to explain some unclear answers found in the questionnaire.

Interviews with the respondents were conducted in the teacher training institute they attended. The room used for interviewing was a counselling room in which a non-threatening environment could help respondents to express their feelings about English learning. The researcher first thanked them for participating in this study and stated the purpose of the interviews and how it would be conducted. Respondents were also reminded that the interview would be tape-recorded and their responses would remain confidential. Therefore, the names were disguised.

Descriptive analyses would not only be used to project students' view on CBLT but also whether they had employed the study skills throughout the process of performing tasks, i.e. doing assignment. The learning outcomes were also validated by students' self-reported data on whether they perceived themselves had successfully acquired the target language skills.

\section{IMPLEMENTATION OF CBLT FOR PRE-SERVICE TEACHERS OF CHINESE}

\subsection{Design: Objectives, syllabus, learning activities, role of learners, teachers and materials}

\subsubsection{Objectives}

This study chose an English foundation course called "Foundations in English" offered to a group of non-English major students of a tertiary institute in Hong Kong. The module outline clearly stated, "This module provides the opportunities for students to develop competence in academic language skills as a basis for core and optional studies in the programme by enabling them to reflect on the role of English in their current and future learning and identify appropriate strategies for enhancement." The aim of the module was to enable students to develop competence in using English for academic purposes and to raise their awareness of the role of English in their current and future learning. That is, to enable students to (1) understand the role of English as a tool for learning and reflect in their own competence in using English; (2) develop competence in using English as a tool for learning in academic and professional contexts; (3) develop their ability to monitor the effectiveness of their use of English in academic and professional contexts; (4) produce an expository text demonstrating command of academic writing conventions.

\subsubsection{Outcomes}

By the end of the course, students were required to produce several learning outcomes. A portfolio of tutorial work and/or self-access tasks (including one appropriately referenced expository text with guided reflection on the task completion process, a small scale research project with reflection on the learning experience and an oral presentation, and a monthly 
English journal) demonstrating the ability to use English as a tool for learning and to selfevaluate English proficiency with regard to identified personal English development goals was required to be produced by the participants.

In other words, the monthly English journal focuses on students' progress on self-access English learning. For the small scale academic research project, students were required to work in small groups of around 4 and the portfolio should include preparatory work and research materials (e.g. questionnaires), a research report, a reflection on the learning experience by each member of the group. Each member would also take part in an oral presentation on the project after their small scale research had been completed.

\subsubsection{Syllabus and learning activities}

In this study, the participants' English course was a 40-hour English course. Each session was a two-hour session. There were 20 sessions in total running throughout the year. In the course design, teaching strategies were deliberately designed to help learners to achieve specific learning objectives. Lessons were developed based on the theory of scaffolding. However, the questions posed are: Can students acquire the skills they are required to? How do they respond to competency-based ESL teaching? How effective is their learning?

CBLT was based on a functional and interactional perspective on the nature of language. This paper sought to teach language in relation to the social contexts in which it was used. In this case, students were required to learn academic English which was believed to be of usefulness to students' professional development especially if they were to pursue studies in an international context. Students were required to produce several pieces of assignments using academic English at the end of the course. During the whole year, curriculum and material were designed to cater for the learning outcomes in the hope that students could achieve the objectives of the module. However, it drew another question: Do pre-service teachers of Chinese need to learn academic English if they are not prepared to use English as substantially as Chinese in the future? To what extent English would be useful for Chinese teachers in their professional development? I would like to investigate how they respond to these questions.

\subsubsection{Skills Needed for the Course}

In this course, based on the assignments requirements, students needed to develop certain skills as autonomous learners. According to Benson (2001), there were skills needed under different study situations. The following table summarised and extracted the necessary skills based on Benson's (2001) and I added into elements that were missed out in this context. They were informal style of writing and oral presentation. This paper categorised the study skills needed under the expected learning outcomes of the course in the following table. 
Table 2. Study skills (adapted from Benson, 2001)

\begin{tabular}{|c|c|c|}
\hline Assignments & Study Situations & Study Skills Needed \\
\hline $\begin{array}{l}\quad \text { Expository Writing } \\
0 \quad \text { Small-scale } \\
\text { Research Report }\end{array}$ & Reading & $\begin{array}{ll} & \text { Reading efficiently: comprehension and speed } \\
& \text { Scanning and skimming } \\
0 & \text { Evaluating } \\
0 & \text { Understanding and analyzing data (graphs and diagrams) } \\
& \text { Note-making, arranging notes in hierarchy of importance } \\
0 & \text { Summarizing and paraphrasing }\end{array}$ \\
\hline $\begin{array}{l}\text { Expository Writing } \\
\text { Small-scale } \\
\text { Research Report }\end{array}$ & $\begin{array}{l}\text { Reference skills: } \\
\text { Library use } \\
\text { Research and } \\
\text { reference skills }\end{array}$ & $\begin{array}{l}\text { Using the contents/index pages } \\
\text { Using a dictionary efficiently } \\
\text { Understanding classification systems } \\
\text { Using a library catalogue on cards, microfilm, computer } \\
\text { Finding information quickly } \\
\text { Collating information }\end{array}$ \\
\hline $\begin{array}{l}\text { Expository Writing } \\
0 \quad \text { Small-scale } \\
\text { Research Report }\end{array}$ & $\begin{array}{l}\text { Writing } \\
\text { essays/research } \\
\text { paper }\end{array}$ & $\begin{array}{ll} & \text { Essay planning } \\
0 & \text { Writing drafts } \\
0 & \text { Revising drafts } \\
& \text { Summarizing, paraphrasing and synthesising } \\
0 & \text { Continuous writing in an academic style } \\
0 & \text { Using quotations, footnotes, biography } \\
\square & \text { Finding and analyzing evidence, using data } \\
\text { appropriately }\end{array}$ \\
\hline $\begin{array}{l}\text { Small-scale Research } \\
\text { Report }\end{array}$ & Research & $\begin{array}{l}\text { Conducting interviews; Designing questionnaires; Undertaking } \\
\text { surveys }\end{array}$ \\
\hline Journal writing & Informal writing & $\begin{array}{l}\text { Personal reflection; Recalling; Mnemonics; Organizing ideas; } \\
\text { Evaluating learning process; Self-access to online English } \\
\text { enhancement websites; Informal writing style }\end{array}$ \\
\hline Oral presentation & Oral skills & $\begin{array}{l}\text { Giving formal speech; Intonation; Attitude; Eye-contact; } \\
\text { Communicative; Voice; Pronunciation; Explaining; Describing; } \\
\text { Justifying }\end{array}$ \\
\hline
\end{tabular}

\subsubsection{Assessment criteria}

In this course, criteria for assessing oral presentation and written assignments were clearly stated. Students were given assessment descriptors at the beginning of the course. The assumption underlying the generic speaking criteria was that students doing oral tasks in different courses and on different programmes of the same type should be learning and be assessed at about the same level. It should be noted that the categories did not carry equal weighting; they were weighted in accordance with the nature and requirements of the task as specified in the assignments. The criteria also served to give useful feedback to students on their level of performance. Appendix 1 showed an example of the above-mentioned generic criteria for assessing oral assignments.

\section{Results AND Discussions}

\subsection{Students' views on CBLT (RQ1)}

It is evident that students held very strong preferences for English learning (see appendix 2). According to the statistical results, the means of student preferences for English learning 
and student needs for learning English are 4.36 and 4.17 respectively. Although they are preservice teachers of Chinese, they do not hold a negative attitude towards English learning and they see English learning very importantly. The very importance of learning English is of no doubt in students' eyes regardless of their background or future career plan. According to one respondent, he described English as an international language which all teachers of all languages should learn so as to broaden their world knowledge in respect of exchanging ideas on teaching which excel their professional development.

However, questionnaire item (3) under students' preference for English learning projects a picture that students have very strong preferences for English learning in general except item (3) "If I had a choice to take language course, I would not rather take Chinese than English." That is, students would rather improve their Chinese proficiency than English if they are given a choice. This could be explained by the fact that all Chinese major students are required to pass a national Putonghua proficiency test before they graduate and become a teacher. Since Cantonese is the mother tongue of most students, they would rather spend more time improving Putonghua rather than English. The need for improving Putonghua is more of an imminent need to the Chinese teachers-to-be. Students predicted that the trend of using Putonghua to teach Chinese is inevitable and proficiency of Putonghua is certainly a must for future Chinese language teachers in Hong Kong.

This result drew a fundamental yet significant question to the principle of curriculum design "Should foreign language teaching and learning give way to second language teaching and learning if students are not yet confident in their second language which is at high stake?" Curriculum planners need to take students' imminent needs into account that these needs and their preferences have to be accommodated. Collaboration with other departments and analysis of students' preferences has to be carefully researched in order to avoid direct competition from a crucial second language course. This is the situation one tutor mentioned in an interview, "No matter how I stressed the importance of English to the class and of course students agreed with me, I still could not buy more time from the students because students need to learn better Putonghua in order to be a proficient Chinese teacher which I fully understand. You can't simply please everybody, can you? My course therefore is a victim of direct competition with a Putonghua course."

In this study, this English course was to be taken by students in their first year studying in the teacher training institute. A better way to enhance the effectiveness of the competencybased English language course is to change it into a course to be taken in students' second year of studies as students would be more assured after one year of Putonghua learning. Students would also be sure whether they were to be teachers or not and English learning would then turn into a value to be added in their teaching career. Timing of the course taken by learners can make a difference which needs to be made possible by collaborating among departments.

Item (6) "Whenever I write diary, I do write in English." obviously holding a lower mean score of 2.50 which implied that students hold an opposite opinion that using English to write journal is what they need to learn because they do not use English to write journals at all, as one of the students expressed, "Writing diary is very personal and you put all your secrets and feelings in the dairy. Using English can't express fully what I want to say. Even if I do write in English, I don't think I will understand what I wanted to write at the moment when I read it again in the future. Chinese is my mother tongue and I can express myself 
freely without any language barrier." Students' response signified that giving presentation in English and writing English academic paper are appropriately designed for students to learn because they are of instrumental use but not writing diary. One student said in the interview, "I know that giving presentation and writing academic papers in English will be useful for my future career so there is a reason for learning. Writing dairy in English? I don't think it will help my career. This assignment is not in line with other assignments in terms of nature." Another participant also indicated, "Using dairy to monitor my online English learning process is not simply what people would normally do, not to mention it is what we need." Based on the principle of competency-based language teaching, assignments designed are to cater for learners' specific needs as Schneck (1978) stated, "Competency-based education has much in common with such approaches to learning as performance-based and is adaptive to the changing needs of students, teachers and the community." Course evaluation and module reviewing are the necessary steps to guarantee the course is designed to cater for learners' needs.

This result echoed the results when participants were asked to comment on assignment and assessment. The means of assignment and assessment are 3.53 and 3.23 respectively which are significantly lower than those of students' preferences and needs on English learning.

The opposite results found reflected the fact that students could see the importance of learning English but they see doing assignments as the course requirement with no immediate effect on improving English. As one student indicated that, "This is only a 40-hour course, we do not expect at all, our English can be improved within one year. Doing assignments are just for assessment purposes not improving our English. If I had a choice, I would rather have alternate assessment methods which really force me to learn. For example, class participation and portfolio." The student's response implied the assessment method needs to be revisited accordingly.

Also, students found the assessment descriptors are not as useful in helping them to achieve what they need to. One student explained, "We never read the fine prints of the assessment descriptors because they looked so similar between a pass and a credit. You need to really compare the two to see the differences between a B and a C. I am what I am. Knowing the assessment descriptor can't improve my English, can it?" The student's response showed that the introduction of assessment descriptors is necessary and its importance should be stressed at the beginning as well as throughout the course. Using sample scripts to demonstrate how these sample scripts practically related and refer to the assessment descriptors will help students understand the importance of the descriptors. Asking students to assess each piece of the sample and ask them to justify the grades they give may help students put themselves into what the course requirements are and know the details of the assessment criteria. Comparison and contrast can also be made during their process of assessing sample works.

Another reason affecting students' opinion towards the assessment descriptors is that students in Hong Kong are very much used to formative assessment as most assessments were done on formative basis. As Gonczi et al (1993) pointed out, "performance is what directly observable, whereas competence is not directly observable, rather it is inferred from performance, this is why competencies were defined as combinations of attributes that underlie successful performance." To increase students' sensitivity to competency-based assessment, teachers play a crucial role in promoting and increasing students' awareness are crucial. 
Table 3. Students' views towards CBLT.

\begin{tabular}{|c|c|c|c|c|}
\hline Rank & Item & & Mean & Std. Deviation \\
\hline 1 & 4. & $\begin{array}{l}\text { I think university students should also take } \\
\text { English language course. }\end{array}$ & 5.23 & 1.478 \\
\hline 2 & 1. & $\begin{array}{l}\text { I want to take English course to improve my } \\
\text { English proficiency. }\end{array}$ & 5.09 & .811 \\
\hline 3 & 8 & $\begin{array}{l}\text { As a Chinese teacher, I can also see the reasons } \\
\text { for learning English. }\end{array}$ & 4.95 & 1.133 \\
\hline 4 & 5 & $\begin{array}{l}\text { I can see the need of using English to give a } \\
\text { presentation. }\end{array}$ & 4.82 & .907 \\
\hline 5 & 9 & $\begin{array}{l}\text { I can see reasons for learning how to write } \\
\text { expository writing. }\end{array}$ & 4.45 & 1.011 \\
\hline 6 & 7 & $\begin{array}{l}\text { I can see the need to use English to write } \\
\text { academic paper. }\end{array}$ & 4.41 & 1.260 \\
\hline 7 & 2. & $\begin{array}{l}\text { Even if I were not required to take an English } \\
\text { language course, I would still want to take one. }\end{array}$ & 4.27 & 1.032 \\
\hline 8 & 12 & $\begin{array}{l}\text { The assignments required in the course can help } \\
\text { me develop my professional development. }\end{array}$ & 3.41 & 1.141 \\
\hline 9 & 15 & $\begin{array}{l}\text { The assessment criteria gives me a good idea of } \\
\text { how much effort I need to put in order to get the } \\
\text { grade I would like to get. }\end{array}$ & 3.41 & 1.141 \\
\hline 10 & 11 & $\begin{array}{l}\text { I am sure what learning outcomes I need to } \\
\text { achieve in the English course. }\end{array}$ & 3.32 & 1.086 \\
\hline
\end{tabular}

From Table 3, items (4), (1), (8), (5), (9) and (7) received higher degree of means in comparison with others. They are "I think university students should also take English language course." "I want to take English course to improve my English proficiency." "As a Chinese teacher, I can also see the reasons for learning English." "I can see the need for using English to give a presentation." "I can see reasons for learning how to write expository writing." and "I can see the need to use English to write academic paper."

The results could fall into a general pattern students were very much aware of the need in learning English even if they were not going to use English as much as Chinese in their future career. They knew that English is an important value to be added to their professional teacher's development. As one student said, "I expect myself to have job promotion in the future, maybe become a school principal or work for the government. English is definitely a must to help my career advancement. I have never met a school head who can't speak English." Also, students saw English as an important part of learning because they were encouraged to learn English at a very young age and the importance of English learning had been heavily stressed in most Asian countries. English learning seemed to be an inevitable part of their learning. "Inevitable" in a sense that they "feel strange to stop learning English" as stated by one of the participants.

\subsection{Study skills acquired and employed by learners (RQ2)}

There are two reasons for competency-based language education. The first is that competency-based language education is a good method for validating the achievement of basic skills. The second is that competency-based language education is a good method for ensuring the total correlation of curriculum, assessment and instruction. These two are the core questions I looked at when examining the effectiveness of implementing competencybased language education in a group of pre-service teachers of Chinese. 
This study therefore attempted to investigate the effectiveness of the implementation of CBLT. Appendix 3a showed the results of how frequently the participants think they used the acquired study skills. Appendix $3 \mathrm{~b}$ showed the results of how frequently the participants employed the overall language skills. 3 referred to the skills they always employed; 2 was the skills they sometimes employ and 1 was the skills they never employed.

When students were asked how often they employed the above skills they learnt, it is obvious that students had employed all the skills the course aimed for the students to achieve (See appendix $3 a \& 3 b$ ). The skill with the highest means is essay writing. Reading, oral, finding references, informal writing and research skills are then followed. It is not surprising to see that research skills are the skills employed least as this is the first year students were exposed to academic English and research papers. For informal writing skills, students reckoned that they did not employ these skills as much because they usually used Chinese during their daily lives which echoed our findings found in the previous section. While for the skills most frequently employed, students found writing a draft, efficiency in reading, using dictionary, using appropriate voice during public speaking, employing appropriate eye-contact with audience when speaking and understanding data are skills they employed most often. These skills are the skills they are most familiar with because teachers in the past mentioned these skills relatively more often than the skills that were first introduced this year. These results posed one fundamental question to syllabus design, "Will it be more effective if we teach students how to find references and write research report first?" and "How should curriculum planners sequence learning activities?" Priorities should also be established in the curriculum process by its nature and purpose.

\subsection{Outcomes of learning (RQ3)}

When students were asked to judge if they had successfully acquired the skills listed above, it showed that paraphrasing, drafting, pronunciation, explaining and describing are the only skills students thought that they have successfully acquired, with the percentage of over $50 \%$ (see Appendix 4). However, skills claimed by students that they had successfully acquired are the skills that they had been learning for over 12 years since primary schools. They are "reading with efficiency" "note-taking" "paraphrasing" "writing draft" "using online English enhancement resources to improve English" "use appropriate voice when speaking" "speak with appropriate pronunciation" "explaining details" "describing details" and "justifying claims".

However, as for those skills that were newly introduced to students only at the beginning of the semester and had never been taught in secondary school settings, students were not certain whether they had acquired them or not. The most evident ones are scanning, skimming, finding information, finding evidence to support claims in essay, interviewing, forming and analyzing questionnaires, doing surveys, writing personal reflection, evaluating evidence and speaking with appropriate intonation.

Based on the above results, one can see that there are only 10 skills out of 25 skills which are validated by students that they had successfully learnt in the course. These skills indicated by the students were the skills that they were most familiar with because these skills had been taught for many years when the students were still in secondary schools. That is to say, skills in this course that were new to the students should be put more emphasis on and given more instructional emphasis. This may suggest that academic writing and research 
skills need to be developed not only through an one-year-40-hour course but one with longer duration. Lack of continuity in learning arrangements has always been a major criticism of competency-based approach (Campbell 1985, Burton 1987, Nunan 1987, Colman 1991 and Hagan 1992). Learners also lacked a coherent progression of courses and posed an obstacle to learner achievement in language learning (Campbell, 1985).

Other measures like providing individual or small group consultation time between tutor and students should also be arranged to provide more pastoral care, cater for individual learning needs and show more personal care to their academic needs. Through individual consultation, tutors will be able to evaluate and assess the effectiveness of his/her teaching and hence increases the flexibility of the course in respect to catering for learners' needs.

\section{Conclusions}

This study found that students in fact held strong preference for learning English. However, they would rather improve Putonghua in their first year of study. Therefore, curriculum planner should take into account students' need at certain point of time when implementing CBLT. Collaboration across departments is also strongly recommended.

Students also revealed that the assessment descriptors were not useful in helping them to achieve the assessment targets or get a high grade because the descriptors were in relative form. To solve this problem, pedagogical adjustment was strongly recommended. Teachers may consider showing students sample scripts of different grades while explaining the assessment descriptors in details so that students can easily internalize the assessment criteria.

Students also stated that research skills was the study skill that they felt not confident in most while the fours skills — speaking, listening, reading and writing — could be easily acquired and employed. Thus, needs analysis can be done before the commencement of the course and give more instructional emphasis to those skills and areas which students do not feel confident in.

All in all, to enhance the effectiveness of competency-based language teaching, the language programme must be locally developed so that curriculum, instruction and assessment can be correlated with each other. Competency-based language education should also have an instructional emphasis so that the programme is not another form of standardized testing. Based on the above results found, educators should think carefully about whether the right domains are being assessed, whether they are learners' need and what diagnostically one can infer if the performance is not acceptably high.

\section{REFERENCES}

Baartman, L. K. J., Bastiaens, T. J., Kirschner, P. A., van der V. \& Cees P. M. (2006). The Wheel of Competency Assessment: Presenting Quality Criteria for Competency Assessment Programs. Studies in Educational Evaluation, 32 (2), 153-170.

Baines, L. A. \& Stanley, G. K. (2006). The Iatrogenic Consequences of Standards-Based Education. Clearing House: A Journal of Educational Strategies, Issues and Ideas, 79 (3), 119-123. 
Barrie, S. C. (2006). Understanding What We Mean by the Generic Attributes of Graduates. Higher Education: The International Journal of Higher Education and Educational Planning, 51 (2), 215-241.

Benson, P. (2001). Teaching and Researching Autonomy in Language Learning. London: Longman. Biemans, H., Nieuwenhuis, L., Poell, R., Mulder, M. \& Wesselink, R. (2005). Competence-Based VET in the Netherlands: Background and Pitfalls. Journal of Vocational Education and Training, 56 (4), 523-538.

Bradly, L. H. (1989). Complete Guide to Competency-Based Education: Practical Techniques for Planning, Developing, Implementing and Evaluating Your Program. New Jersey: Prentice Hall.

Brindley, G. (1994). Competency-based assessment in second language programs: Some issues and questions. Prospect, 9(2), 43-55

Bunda, M. A. \& Sanders, J. R. (eds.) (1979). Practices and Problems in Competency-Based Education. UMI: A Bell and Howell Company.

Burns, A. \& Hood, S. (1994). The Competency-based Curriculum in Action: Investigating course design practices, Prospect, 9(2), 76-89

Burrows, C. (1994). The AMEP meets CBT: A literature review. Prospect 9(2), 18-29.

Burton, J. (1987) (ed.). Implementing the learner-centred curriculum. Sydney: NECLTR.

Campbell, J. (1985). Towards active voice: Report of the committee of review of the adult migrant education program. Canberra: ACTPS.

Caniels, M. C. J. (2004). Teaching Competencies Efficiently through the Internet-A Practical Example. European Journal: Vocational Training, 34, 40-48.

Chang, C. (2006). Development of Competency-Based Web Learning Material and Effect Evaluation of Self-Directed Learning Aptitudes on Learning Achievements. Interactive Learning Environments, 14 (3), 265-286.

Chang, C. (2007). Evaluating the Effects of Competency-Based Web Learning on Self-Directed Learning Aptitudes. Journal of Computers in Mathematics and Science Teaching, 26 (3), 197-216.

Chyung, S. Y., Stepich, D. \& Cox, D. (2006). Building a Competency-Based Curriculum Architecture to Educate 21st-Century Business Practitioner. Journal of Education for Business, 81 (6), 307-314.

Colman, P. (1992). Learner pathways: An historical overview. Interchange, 19, 5-9.

Dalton, J. \& Bottomley, (1994) From proficiency to competencies, Prospect 9(2), 70-75

Docking, R (1994) Competency-based curricula-the big picture, Prospect 9(2), 8-17.

Gonczi, A., Hager, A. and Athanasou, J. (1993). The development of competency-based assessment strategies for the professions. Canberra: Australian Government Publishing Service.

Guerro, M. D. (2004). Acquiring Academic English in One Year: An Unlikely Proposition for English Language Learners. Urban Education. Corwin Press. 30 (2):172-199.

Guskey, T. R. (2005). Mapping the Road to Proficiency. Educational Leadership, 63 (3), 32-38.

Hagan, P. (1994). Competency-based curriculum: the NSW AMES experience, Prospect 9(2), 3039

Heidemann, S., Chang, C. J. \& Menninga, B. (2005). When Teachers Are Learning, Children Are Too: Teaching Teachers about Assessment. Young Children, 60 (3), 86-92.

http://www.shanghaidaily.com/sp/article/2007/200707/20070703/article 321893.htm (last accessed on 1 August 2007)

Jackson, M. J., Gallis, H. A., Gilman, S. C., Grossman, M., Holzman, G. B., Marquis, D. \& Trusky, S. K. (2007). The Need for Specialty Curricula Based on Core Competencies: A White 
Paper of the Conjoint Committee on Continuing Medical Education. Journal of Continuing Education in the Health Professions, 27 (2), 124-128.

Jang, S. \& Kim, N. (2004). Transition from High School to Higher Education and Work in Korea, from the Competency-Based Education Perspective. International Journal of Educational Development, 24 (6), 691-703.

Johnson, K. (1998) Language and education in Hong Kong. In M. C. Pennington (ed.) Language in Hong Kong at Century's End. Hong Kong: Hong Kong University Press.

Jorgensen, H. (2005). Program Prepares Students for Chemical-Processing Careers. Tech Directions, 65 (1), 16-18.

Kaslow, N. J. (2004). Competencies in Professional Psychology. American Psychologist, 59 (8), 774-781.

Kwo, O. W. Y. (1994) The teaching of Putonghua in Hong Kong schools: Language education in a changing economic and political context. In G. A. Postiglione (ed.) Education and Society in Hong Kong - toward One Country Two Systems. pp. 184-203. Hong Kong: Chinese University Press.

Lord, R. (1987) Language policy and planning in Hong Kong: Past, present and (especially) future. In R. Lord and H. N. L. Cheng (eds.) Language Education in Hong Kong. pp.3-26. Hong Kong: Chinese University Press.

Madya, S. (2003). Designing competency-based TEFL for S1 Students to Foster Professionalism. http://www.geocities.com/nuesp_indonesia/paper_18.htm (last accessed on 29 July 2007)

Mehrens, W. (1992). Using performance assessment for accountability purposes. Educational measurement: Issues and practices, 11, 1.

Meier, F. E. (1992). Competency-Based Instruction for Teachers of Students with Special Learning Needs. Allyn and Bacon.

Mulder, M., Weigel, T. \& Collins, K. (2007). The Concept of Competence in the Development of Vocational Education and Training in Selected EU Member States: A Critical Analysis. Journal of Vocational Education and Training, 59(1), 67-88.

Nahrwold, D. L. (2005). Continuing Medical Education Reform for Competency-Based Education and Assessment. Journal of Continuing Education in the Health Professions, 25 (3), 168173.

Nunan, D. (1987). The teacher as curriculum developer. Sydney: NCELTR.

Pennycook, A. (1995). English in the world / The world in English. In J. W. Tollefson (ed.) Power and Inequality in Language Education. New York: Cambridge University Press.

Pierson, H. (1994) Cantonese, English, or Putonghua - Unresolved communicative issue in Hong Kong future. In G. A. Postiglione (ed.) Education and Society in Hong Kong - toward One Country Two Systems. pp. 168-83. Hong Kong: Chinese University Press.

Richards, J. C. and Rodgers, T. S. (2001). Approaches and Methods in Language Teaching. ( $2^{\text {nd }}$ edition) Cambridge University Press. p.141-149.

Sampson, D., Karampiperis, P. \& Fytros, D. (2007). Developing a Common Metadata Model for Competencies Description. Interactive Learning Environments, 15 (2), 137-150.

Schneck, E. A. (1978). A Guide to Identifying High School Graduation Competencies. Portland. Oreg.: Northwest Regional Educational Laboratory.

Shanghai Daily (2007) Hong Kong eager learn Mandarin. 3 July 2007.

Van der Linden, J. \& Mendonca, M. (2007). From Competence-Based Teaching to Competence Based Learning: The Case of Generic Competencies in the Faculty of Education at the Eduardo Mondlane University in Mozambique. Perspectives in Education, 24 (3), 37-51.

Williamson, B. (2007). Viewpoints: Teaching and Learning with Games? Learning, Media and Technology, 32 (1), 99-105. 


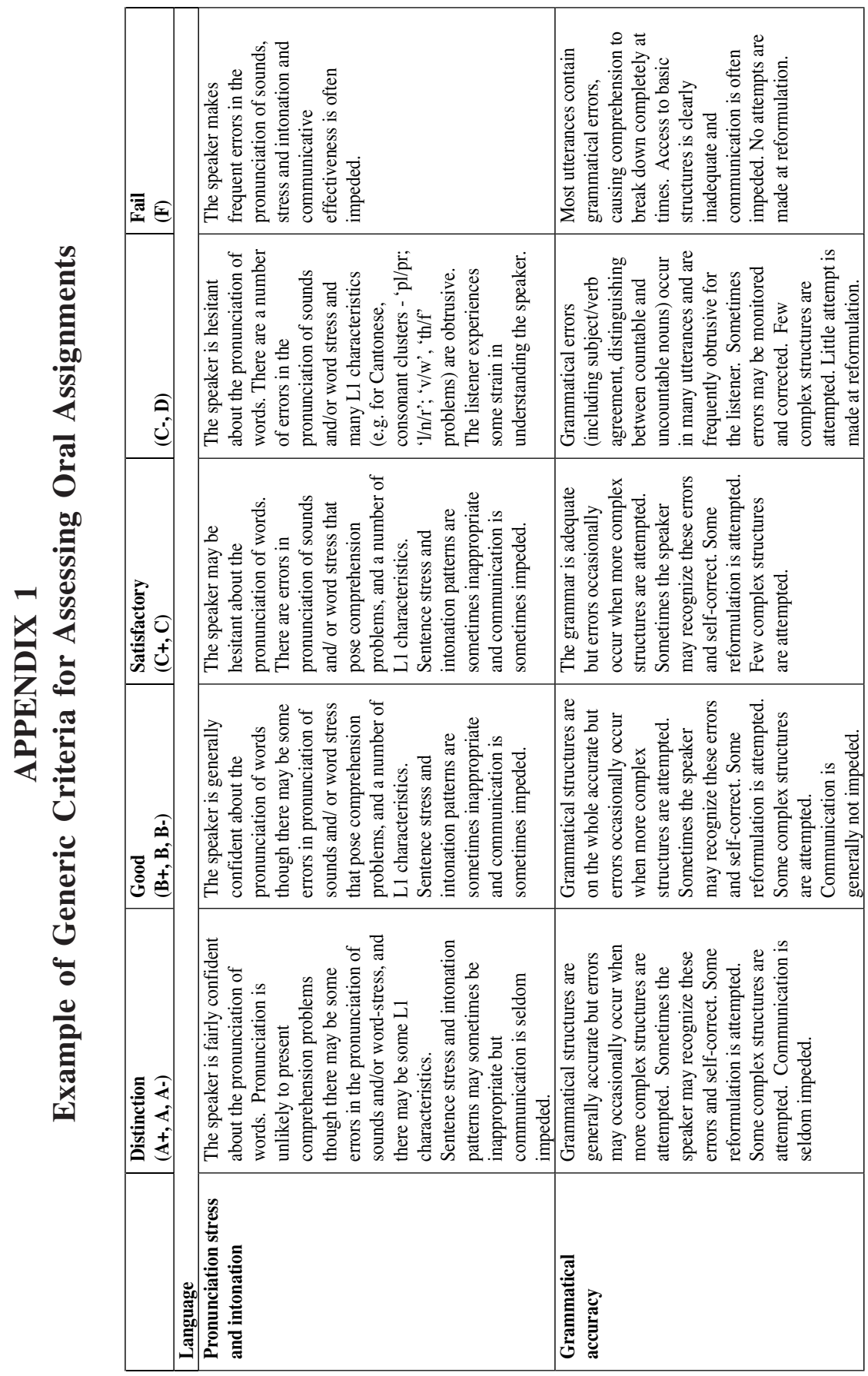




\section{APPENDIX 2}

\section{A. Students' views on CBLT}

\begin{tabular}{|c|c|c|c|}
\hline & & Mean & Std. Deviation \\
\hline & \multicolumn{3}{|l|}{ Students' preference on English learning } \\
\hline 1. & $\begin{array}{l}\text { I want to take English course to improve my } \\
\text { English proficiency. }\end{array}$ & 5.09 & .811 \\
\hline 2. & $\begin{array}{l}\text { Even if I were not required to take an English } \\
\text { language course, I would still want to take } \\
\text { one. }\end{array}$ & 4.27 & 1.032 \\
\hline 3. & $\begin{array}{l}\text { If I had a choice to take language course, I } \\
\text { would not rather take Chinese than English. }\end{array}$ & 2.86 & 1.390 \\
\hline \multirow[t]{2}{*}{4.} & $\begin{array}{l}\text { I think university students should also take } \\
\text { English language course. }\end{array}$ & 5.23 & 1.478 \\
\hline & Students' needs for learning English & & \\
\hline 5 & $\begin{array}{l}\text { I can see the need for using English to give a } \\
\text { presentation. }\end{array}$ & 4.82 & .907 \\
\hline 6 & Whenever I write diary, I do write in English. & 2.50 & 1.336 \\
\hline 7 & $\begin{array}{l}\text { I can see the need to use English to write } \\
\text { academic paper. }\end{array}$ & 4.41 & 1.260 \\
\hline \multirow[t]{2}{*}{8} & $\begin{array}{l}\text { As a Chinese teacher, I can also see the } \\
\text { reasons for learning English. }\end{array}$ & 4.95 & 1.133 \\
\hline & Assignment & & \\
\hline 9 & $\begin{array}{l}\text { I can see reasons for learning how to write } \\
\text { expository writing. }\end{array}$ & 4.45 & 1.011 \\
\hline 10 & $\begin{array}{l}\text { Even if I am required to do assignments, I am } \\
\text { still willing to do them. }\end{array}$ & 2.95 & 1.174 \\
\hline 11 & $\begin{array}{l}\text { I am sure what learning outcomes I need to } \\
\text { achieve in the English course. }\end{array}$ & 3.32 & 1.086 \\
\hline \multirow[t]{2}{*}{12} & $\begin{array}{l}\text { The assignments required in the course can } \\
\text { help me develop my professional } \\
\text { development. }\end{array}$ & 3.41 & 1.141 \\
\hline & Assessment & & \\
\hline 13 & $\begin{array}{l}\text { The descriptors of assessment can help me } \\
\text { focus on what learning outcomes I need to } \\
\text { achieve. }\end{array}$ & 3.27 & .985 \\
\hline 14 & $\begin{array}{l}\text { It is clear to me what I need to achieve in this } \\
\text { course. }\end{array}$ & 3.00 & 1.155 \\
\hline 15 & $\begin{array}{l}\text { The assessment criteria give me a good idea of } \\
\text { how much effort I need to put in order to get } \\
\text { the grade I would like to get. }\end{array}$ & 3.41 & 1.141 \\
\hline 16 & $\begin{array}{l}\text { The use of descriptors of assessment avoids } \\
\text { teacher's bias towards certain students. }\end{array}$ & 3.27 & 1.162 \\
\hline
\end{tabular}




\section{B. Students' views on CBLT}

\begin{tabular}{|l|c|}
\hline Students' views on competency-based language education & Mean \\
\hline Students' preferences on English learning & 4.36 \\
\hline Students' needs for learning English & 4.17 \\
\hline Assignment & 3.53 \\
\hline Assessment & 3.23 \\
\hline
\end{tabular}

\section{APPENDIX 3}

\section{A. Students' views on CBLT}

\begin{tabular}{|c|c|c|}
\hline & Mean & Std. Deviation \\
\hline Writing a draft & 2.27 & .550 \\
\hline Efficiency in reading & 2.18 & .501 \\
\hline Using dictionary & 2.18 & .664 \\
\hline Using appropriate voice during public speaking & 2.14 & .560 \\
\hline $\begin{array}{l}\text { Employing appropriate eye-contact with audience when } \\
\text { speaking }\end{array}$ & 2.14 & .468 \\
\hline Understanding data & 2.14 & .468 \\
\hline Adopting informal writing style & 2.09 & .610 \\
\hline Synthesising information & 2.09 & .610 \\
\hline Scanning and skimming & 2.09 & .610 \\
\hline Accurate pronunciation & 2.05 & .486 \\
\hline Possessing communicative competence & 2.05 & .486 \\
\hline Using appropriate attitudes when speaking & 2.05 & .653 \\
\hline Paraphrasing & 2.05 & .653 \\
\hline Note-making & 2.05 & .653 \\
\hline Describing details accurately & 2.00 & .309 \\
\hline Evaluating information & 2.00 & .436 \\
\hline Explaining details & 2.00 & .617 \\
\hline Using index and content page correctly & 2.00 & .436 \\
\hline Employing correct intonation & 1.95 & .575 \\
\hline Being able to use online English enhancement websites & 1.95 & .653 \\
\hline Finding information quickly & 1.91 & .610 \\
\hline Organising ideas & 1.91 & .526 \\
\hline Personal reflection & 1.91 & .526 \\
\hline Recalling & 1.91 & .610 \\
\hline Justifying claims & 1.86 & .351 \\
\hline Providing sound evidence to support claims & 1.86 & .640 \\
\hline Employ appropriate academic style & 1.82 & .501 \\
\hline Delivering formal speech & 1.77 & .612 \\
\hline Able to use library catalogue & 1.73 & .631 \\
\hline Understanding classification & 1.73 & .631 \\
\hline Mnemonics & 1.68 & .477 \\
\hline Employing appropriate Interview strategies & 1.68 & .477 \\
\hline Using quotations to support claims & 1.68 & .477 \\
\hline Collating information & 1.68 & .568 \\
\hline Setting questionnaires & 1.64 & .492 \\
\hline Evaluating process & 1.64 & .492 \\
\hline Doing surveys & 1.50 & .512 \\
\hline
\end{tabular}




\section{B. Students' views on CBLT}

\begin{tabular}{|l|c|}
\hline Skills employed by students & Mean \\
\hline Essay writing & 2.14 \\
\hline Reading & 2.09 \\
\hline Oral & 2.00 \\
\hline Finding references & 1.87 \\
\hline Informal writing & 1.87 \\
\hline Research & 1.72 \\
\hline
\end{tabular}

APPENDIX 4

Study skills acquired by learners

\begin{tabular}{|c|c|c|}
\hline & & Percent \\
\hline \multirow[t]{2}{*}{ Read with efficiency } & No & 50.0 \\
\hline & Yes & 50.0 \\
\hline \multirow{2}{*}{ Scanning and skimming } & No & 68.2 \\
\hline & Yes & 31.8 \\
\hline \multirow[t]{2}{*}{ Evaluating evidence } & No & 68.2 \\
\hline & Yes & 31.8 \\
\hline \multirow[t]{2}{*}{ Understanding data } & No & 59.1 \\
\hline & Yes & 40.9 \\
\hline \multirow[t]{2}{*}{ Note-making } & No & 45.5 \\
\hline & Yes & 54.5 \\
\hline \multirow[t]{2}{*}{ Paraphrasing } & No & 22.7 \\
\hline & Yes & 77.3 \\
\hline \multirow[t]{2}{*}{ Reading index and content page } & No & 54.5 \\
\hline & Yes & 45.5 \\
\hline \multirow[t]{2}{*}{ Finding information quickly } & No & 63.6 \\
\hline & Yes & 36.4 \\
\hline \multirow[t]{2}{*}{ Collating information } & No & 54.5 \\
\hline & Yes & 45.5 \\
\hline \multirow[t]{2}{*}{ Writing drafts } & No & 40.9 \\
\hline & Yes & 59.1 \\
\hline \multirow[t]{2}{*}{ Use relevant evidence to support claims in writing } & No & 77.3 \\
\hline & Yes & 22.7 \\
\hline \multirow[t]{2}{*}{ Interviewing } & No & 68.2 \\
\hline & Yes & 31.8 \\
\hline
\end{tabular}




\begin{tabular}{|c|c|c|}
\hline Writing questionnaires & $\begin{array}{l}\text { No } \\
\text { Yes }\end{array}$ & $\begin{array}{l}77.3 \\
22.7\end{array}$ \\
\hline Doing surveys & $\begin{array}{l}\text { No } \\
\text { Yes }\end{array}$ & $\begin{array}{l}81.8 \\
18.2\end{array}$ \\
\hline Writing personal reflection & $\begin{array}{l}\text { No } \\
\text { Yes }\end{array}$ & $\begin{array}{l}63.6 \\
36.4\end{array}$ \\
\hline Evaluating learning process & $\begin{array}{l}\text { No } \\
\text { Yes }\end{array}$ & $\begin{array}{l}63.6 \\
36.4\end{array}$ \\
\hline Using online English enhancement resources & $\begin{array}{l}\text { No } \\
\text { Yes }\end{array}$ & $\begin{array}{l}50.0 \\
50.0\end{array}$ \\
\hline Adopting informal writing style & $\begin{array}{l}\text { No } \\
\text { Yes }\end{array}$ & $\begin{array}{l}59.1 \\
40.9\end{array}$ \\
\hline Giving formal speech & $\begin{array}{l}\text { No } \\
\text { Yes }\end{array}$ & $\begin{array}{l}59.1 \\
40.9\end{array}$ \\
\hline Use appropriate intonation when speaking & $\begin{array}{l}\text { No } \\
\text { Yes }\end{array}$ & $\begin{array}{l}72.7 \\
27.3\end{array}$ \\
\hline Use appropriate voice when speaking & $\begin{array}{l}\text { No } \\
\text { Yes }\end{array}$ & $\begin{array}{l}50.0 \\
50.0\end{array}$ \\
\hline Speak with adequate pronunciation & $\begin{array}{l}\text { No } \\
\text { Yes }\end{array}$ & $\begin{array}{l}27.3 \\
72.7\end{array}$ \\
\hline Explaining details & $\begin{array}{l}\text { No } \\
\text { Yes }\end{array}$ & $\begin{array}{l}31.8 \\
68.2\end{array}$ \\
\hline Describing details & $\begin{array}{l}\text { No } \\
\text { Yes }\end{array}$ & $\begin{array}{l}36.4 \\
63.6\end{array}$ \\
\hline Justifying claims & $\begin{array}{l}\text { No } \\
\text { Yes }\end{array}$ & $\begin{array}{l}59.1 \\
40.9\end{array}$ \\
\hline
\end{tabular}

